\title{
Physicochemical, Cooking Characteristics and Textural Properties of TOX 3145 Milled Rice
}

\author{
Amaka M. Odenigbo ${ }^{1,2}$, Michael Ngadi ${ }^{1}$, Chijioke Ejebe ${ }^{1}$, Noe Woin $^{3} \&$ Sali A. Ndindeng ${ }^{3}$ \\ ${ }^{1}$ Department of Bioresource Engineering, McGill University, Quebec, Canada \\ ${ }^{2}$ Department of Human Nutrition and Dietetics, Michael Okpara University of Agriculture, Umudike, Nigeria \\ ${ }^{3}$ Institute of Agricultural Research for Development (IRAD), Yaoundé, Cameroon \\ Correspondence: Michael Ngadi, Department of Bioresource Engineering, McGill University, 21111 Lakeshore \\ Road, Ste-Anne-de-Bellevue, Quebec, H9X 3V9, Canada. E-mail: amakajesu1@yahoo.com
}

Received: June 23, 2013 Accepted: February 24, 2014 Online Published: February 28, 2014

doi: $10.5539 /$ jr.v3n2p82 URL: http://dx.doi.org/10.5539/jfr.v3n2p82

\begin{abstract}
Quality of rice is an important criterion for the choice and demand by rice consumers and it is determined by physicochemical parameters. The objective of this research was to screen the physical, gelatinization, cooking and textural properties of an improved rice variety cultivated in Cameroon (TOX 3145). Three differently processed samples of TOX 3145: non-parboiled (NP), traditional parboiled (TP) and IRAD parboiled (IRAD) were involved in this study. The result revealed the grain dimension of samples as long and slender shape. The degree of redness among cooked and uncooked grains varied from -0.8 to -1.0 and 0.3 to 1.5 , respectively while yellowness parameter ranged between 0.4 to 4.0 and 7.6 to 8.4 , respectively. Lightness parameter $\left(\mathrm{L}^{*}\right)$ varied from 59.4 to 61.8 in cooked samples. Minimum cooking time among samples was between 17.9-19.7 min. Highest elastic modulus and hardness $(43.3 \mathrm{~N} / \mathrm{mm}$ and $36.8 \mathrm{~N}$, respectively) was found in TP sample. The NP sample had lowest adhesiveness $(-0.76 \mathrm{~J})$ and highest gumminess $(6.40 \mathrm{~J})$. Water uptake was positively correlated with amylose content $(\mathrm{r}=0.84 ; \mathrm{P}<0.05)$ and lightness parameter $(\mathrm{r}=0.92 ; \mathrm{P}<0.05)$.
\end{abstract}

This study provides information on the physical, thermal, gelatinization and cooking characteristics of TOX 3145 rice in its raw and parboiled forms as consumed in Cameroon.

Keywords: milled rice, parboiling, texture, amylose, color parameter, grain dimension, cooking characteristics

\section{Introduction}

In Cameroon, rice has become one of the most growing food sources to families (Goufo, 2008). An estimate of 12.7 to $20 \mathrm{~kg}$ of rice per year is consumed by an individual in Cameroun (Nguefack et al., 2007). The popularity of rice motivated the Cameroonian Government to increase national rice production as well as investing on improved rice varieties for the achievement of national food security (Goufo, 2008).

Presently, several improved rice varieties have been released as a commitment to meeting the increased demand for rice in Africa (Gridley et al., 2002).

Production of rice varieties in different location vary significantly in their grain quality due to genetic and environmental factors (Singh et al., 2005). Grain dimension is also an important quality of rice with varied preference among consumer groups and geographical location (Danbaba et al., 2011; Fan et al., 2006). The quality of rice is a multidimensional property including nutritional composition, cooking, physical and textural characteristics (Bocevska et al., 2009).

Grain quality is an important criterion for the choice and demand by rice consumers (Danbaba et al., 2011). White and translucent grains are rated highly with more preference by rice consumer (Fofana et al., 2011; Adu-Kwarteng et al., 2003). On the other hand, palatability of cooked rice is governed by the textural characteristics (Zhout et al., 2002).

The cooking characteristic of rice is related to grain dimension of milled rice. Bocevska et al. (2009) reported significant correlation of grain elongation during minimum cooking time with thickness $(r=0.7234)$ and width $(\mathrm{r}=0.9134)$ of grains.

The overall quality of rice is influenced by production, harvesting and postharvest operations (Danbaba et al., 
2011). Parboiling, which is one of the post-harvest operations affects physicochemical, textural and cooking characteristics of rice. Several studies have demonstrated that parboiling process improves textural properties such as hardness, cohesiveness, gumminess, chewiness and resilience in cooked grain (Bello et al., 2006; Zhout et al., 2002). Bello et al. (2006) reported harder textural properties in cooked grains of traditional parboiled rice than their non-parboiled counterpart.

Parboiling process that involves high temperature above gelatinization temperature affect the tenderness and colour of the rice grain (Bello et al., 2006).

TOX 3145 is an improved rice variety, which is available to consumers in differently processed forms: parboiled, and non-parboiled milled grains. There is no published data on the physicochemical properties of this rice variety grown in Cameroon. This study therefore aimed at screening the physical, gelatinization, cooking and textural properties of TOX 3145 rice samples.

\section{Materials and Methods}

\subsection{Samples}

Samples of freshly harvested paddy of TOX 3145 rice varieties were collected from a rice farmer in Ndop, Northwest Region of Cameroon during the 2010 harvest season. The samples were harvested by panicle picking and separated into three portions. One portion was the non-parboiled sample (NP), which was dried to $12 \%$ moisture content before milling. The other two portions were parboiled by two different methods namely; Traditional parboiling (TP) and IRAD parboiling (IRAD). The TP sample was parboiled by a farmer's group well known for parboiling rice at a semi-industrial scale in Cameroon. This traditional procedure involved no pre-cleaning of paddy, longer soaking and steaming time $(18-20 \mathrm{hrs})$, soaking temperature about $80{ }^{\circ} \mathrm{C}$, non-uniform distribution of steam during steaming with traditional cooking equipment (barrel drums) and a three stone fire place.

The IRAD sample was prepared by the same farmer's group but the procedure involved an improved parboiling technology which has been code named a Uniform-Steam Parboiling system in IRAD (unpublished report). The Paddy was pre-cleaned, soaked for $12 \mathrm{hrs}$ with the initial soaking temperature being $80^{\circ} \mathrm{C}$. The paddy was then steamed using the improved equipment (Vessel, stand, steam basket) and an improved parboiling stove to ensure uniform distribution of steam.

All samples were milled using a Satake commercial rubber roll milling facility own by the Ndop Rice Miller's Union. The milled rice grains were then brought to McGill University, Canada for analysis.

\subsection{Sample Preparation for Proximate Analysis}

Grains of the rice samples were individually ground using a coffee grinder (SUMEET Multi Grind, India) and passed through a 60 mesh $(0.25 \mathrm{~mm})$ sieve (CETyler, Ontario, Canada).

\subsubsection{Isolation of Starch}

Starch was extracted from rice flour samples by alkaline deproteination method according to Lim et al. (1999) with slight modification. About $100 \mathrm{~g}$ of flour was mixed with $300 \mathrm{ml}$ of $0.5 \% \mathrm{NaOH}$. The mixture was constantly stirred for $4 \mathrm{~h}$ and left to stand for $24 \mathrm{~h}$ at $10^{\circ} \mathrm{C}$. The supernatant was decanted and the solid phase washed several times with distilled water until the $\mathrm{pH}$ of the filtrate was between 6.0 and 6.5. The isolated starch was oven- dried at $40{ }^{\circ} \mathrm{C}$ for $48 \mathrm{~h}$ and later ground in a motar to pass through a $0.55 \mathrm{~mm}$ mesh sieve, then used for amylose determination.

\subsection{Grain Dimension}

A total of 10 unbroken grains were randomly selected from each sample for measurement of length and width. Two different width measurements were taken for each grain and the average was recorded. The measurements were carried out with an electronic digital caliper (Marathon, Inc., Belleville, ON, Canada). The values for weight and width of the 10 grains were recorded as mean \pm SD for each sample.

The measurement of length classifies grains into the following categories: extra short, short $(<5.5 \mathrm{~mm})$, medium (5.5-6.6 mm), long $(>6.6-7.5 \mathrm{~mm})$ and extra long $(>7.5 \mathrm{~mm})$. Whereas the ratio of length to width determines the shape of grains as follows; slender $>3.0$, medium (2.1-3.0), bold (1.1-2.0) and round $(<1.1)$ (Bocevska et al., 2009).

\subsection{Color Characteristics}

Color parameters $\left(L^{*}, a^{*}, b^{*}\right)$ of uncooked and cooked rice grain samples were determined using a spectrophotometer (Konica Minolta, CM-3500d, Minolta Co., Ltd. Osaka, Japan). The instrument was calibrated 
with a black and white standard plate (13371004) before analysis. Illuminant D65 (CIE 1964, 10 Standard Observer) was used. The color coordinates (Lightness, $\mathrm{L}^{*}$; redness, $\mathrm{a}^{*}$; yellowness, $\mathrm{b}^{*}$ ) were calculated in the CIELAB system. The $L^{*}$ value indicates lightness $(100=$ white and $0=$ black $), a^{*}$ value indicates the degree of red-green color, with a higher positive $a^{*}$ value indicating redness. The $b^{*}$ value indicates degree of yellow-blue color, with a higher $\mathrm{b}^{*}$ indicating yellowness. Mean and standard deviation of four replications were reported.

\subsection{Cooking Properties}

\subsubsection{Minimum Cooking Time (MCT)}

Cooking time for samples was determined as described by Mohapatra and Bal (2006). A mass of $5 \mathrm{~g}$ rice grain from each sample was cooked in boiling distilled water $(100 \mathrm{ml})$ at $100 \pm 1{ }^{\circ} \mathrm{C}$ in a water bath. Measurements were taken after $10 \mathrm{~min}$ of cooking and every minute thereafter. The measurements involved collection of 10 grains from the cooking vessel and pressing between two glass slides. The time when minimum of $95 \%$ of the collected boiled grains no longer displayed opaque core or un- gelatinized centres is recorded as the MCT. The rice was then allowed to simmer for another $2 \mathrm{~min}$ to ensure that the core of all grains had been gelatinized. This additional 2 min after the MCT is referred to as Optimum cooking time (Mohapatra \& Bal, 2006).

\subsubsection{Water Uptake Ratio}

Water absorption of cooked rice was determined by the increase in weight of rice after subjecting to MCT as described above. Water uptake ratio was calculated as the ratio of cooked rice grain to weight of uncooked rice grain.

\subsubsection{Elongation ratio}

Elongation ratio was determined by measurement of 10 cooked grains (MCT as described above). Cumulative length of the cooked grains was divided by cumulative length of 10 uncooked grains.

\subsection{Texture Profile Analysis (TPA) of Cooked Rice}

Compression tests on the cooked samples were performed by an Instron Universal Testing Machine (Model 4502, Canton, MA, USA). Samples for the test were prepared by boiling $5 \mathrm{~g}$ grain in $100 \mathrm{ml}$ distilled water at $100 \pm 1$ ${ }^{\circ} \mathrm{C}$ for the minimum cooking time for each sample as described above. The cooked grains were drained of water using a strainer and the test was performed immediately. Five grains were selected from the cooked samples and carefully placed under a cylinder plunger with $25 \mathrm{~mm}$ diameter.

The samples were then compressed in a two-cycle compression to $50 \%$ at $2.5 \mathrm{~mm} / \mathrm{min}$ speed and force-versus-time program with $50 \mathrm{~N}$ load. All textural analyses were replicated three times per sample. The temperature and humidity during tests were $23{ }^{\circ} \mathrm{C}$ and $50 \%$, respectively. Load-displacement curves were obtained. Parameters recorded from the test curves were hardness, elastic modulus, adhesiveness and gumminess.

Hardness and elastic modulus were the maximum force $(\mathrm{N})$ of first compression and slope of the linear section of the load-displacement curve respectively. Adhesiveness is the negative area for the work necessary to pull compressing plunger away from the sample while gumminess is the product of hardness and cohesiveness (ratio of the area under curves of second and first compression cycle).

\subsection{Differential Scanning Calorimeter Analysis (DSC)}

The gelatinization properties were examined by a Differential Scanning Calorimeter (DSC Q100, TAinstruments, Wilmington, $D E$, USA).Heat flow and temperature calibrations of the DSC were performed using pure indium with $28.41 \mathrm{~J} / \mathrm{g}$ heat of fusion and a melting temperature of $156.66^{\circ} \mathrm{C}$. The experimental values were within $\pm 3 \%$ of the literature value.

A mass of $3 \pm 0.01 \mathrm{mg}$ was carefully placed at the centre of a pre weighed aluminium pan $(40 \mu \mathrm{l})$. Considering the moisture content of each sample, appropriate volume of distilled water was added to the pan by a micropipette to achieve a flour/ water ratio of 1:2. The pans were hermetically sealed with TA sample encapsulating press. The sealed pans were stored at room temperature to stabilize for one hour before analysis. The sample pans were placed in the sample cells while an empty pan was placed in the reference cell of the DSC. Samples were heated from 35 to $100{ }^{\circ} \mathrm{C}$ at a rate of $10{ }^{\circ} \mathrm{C} / \mathrm{min}$. The onset $(T \mathrm{o})$, peak (Tp) and conclusion $(T \mathrm{c})$ temperatures of gelatinization were determined. Gelatinization enthalpy $(\Delta H)$ was measured in $\mathrm{J} / \mathrm{g}$ of dried sample weight. 


\subsection{Amylose Determination}

The analytical procedure of Hoover and Ratnayake (2001) was adopted in determination of amylose content. Isolated starch $(20 \mathrm{mg}$ ) was vortexed with $8 \mathrm{ml}$ of $90 \%$ dimethylsulfoxide (DMSO) then incubated in a shaking water bath at $85{ }^{\circ} \mathrm{C}$ for $15 \mathrm{~min}$. Solution was subsequently cooled at room temperature for $45 \mathrm{~min}$ then diluted with DDW to $25 \mathrm{ml}$. Aliquot of $1 \mathrm{ml}$ from the diluted solution was added to $40 \mathrm{ml}$ of DDW then mixed vigorously with $5 \mathrm{ml}$ of iodine solution $(0.0025 \mathrm{M} \mathrm{I} / 0.0065 \mathrm{M} \mathrm{KI}$ mixture). Afterward volume was adjusted to $50 \mathrm{ml}$ with DDW, mixed vigorously and allow to develop colour for $15 \mathrm{~min}$. Absorbance was measured at 600 $\mathrm{nm}$ against a reagent blank. The percentage of amylose was calculated from an equation obtained from the standard curve. Standard curve was generated using mixtures of potato amylose and potato amylopectin (Sigma).

\subsection{Statistical Analysis}

Data were expressed as mean values of replicate measurements. Variation in physical, textural, cooking characteristics and amylose contents among samples were determined by a one-way analysis of variance (ANOVA) followed by Fisher's least significant-difference (LSD) test $(\mathrm{P}<0.05)$. Relationships between study parameters were calculated with Pearson correlation coefficients ( $\mathrm{r}$ ), statistical significance was considered at $\mathrm{P}$ $<0.05$. The statistical software used was SAS version 4.3 (SAS Institute Inc., 2010, Cary, NC, USA).

\section{Results and Discussion}

The dimension of TOX 3145 rice grains are presented in Table 1a. The values for length and width showed slight variation among samples; traditional parboiled had 7.23 and $1.89 \mathrm{~mm}$, respectively, IRAD parboiled (6.85 and $1.87 \mathrm{~mm}$, respectively) and non-parboiled (6.73 and $1.84 \mathrm{~mm}$, respectively). However, the length to width ratio was not statistically different among samples $(\mathrm{P}>0.05)$ which portrayed similarity in size (long) and shape (slender). Fofana et al. (2011) reported slender shape with length to width ratio of $3.51 \mathrm{~mm}$ among the imported rice varieties while improved rice varieties in their study had medium shape with length to width ratio of 2.69.

The amylose content of samples as presented in Table $1 \mathrm{~b}$ indicated highest value in NP (23.61\%) followed by TP (20.61\%) while IRAD sample had $17.13 \%$. Amylose plays a vital role in gelatinization of starch and consequent influence on cooking and eating quality of milled rice (Hermansson \& Svegmark, 1996; Juliano et al., 1981).

Gelatinization properties of samples obtained from DSC curves presented endothermic transition only in the NP sample (Figure 1). NP displayed the following gelatinization temperature: onset temperature $\left(63.42{ }^{\circ} \mathrm{C}\right)$, peak $\left(67.66{ }^{\circ} \mathrm{C}\right)$, completion temperature $\left(74.02{ }^{\circ} \mathrm{C}\right)$ and enthalpy of $0.66 \mathrm{~J} / \mathrm{g}$. These values are comparable with the data reported on 39 milled rice samples from West Africa; onset temperature ranged between 58 to $72 \%$; peak from 66 to $77 \%$ and completion from 70 to $83 \%$ (Traore et al., 2011).

The absence of gelatinization among the two parboiled samples could be attributed to the heating intensity during parboiling operation in these grains. According to Yeh and Li (1996), starch gelatinization is an irreversible process and the disruption of starch granules occurs mainly at temperatures between 70 and $77.5^{\circ} \mathrm{C}$ and almost no starch granules are disintegrated below $55^{\circ} \mathrm{C}$. This finding in our study is not surprising because the parboiling protocol for these two samples involve soaking temperature of $80^{\circ} \mathrm{C}$. Some previous studies had reported significant lower enthalpy among gelatinized samples in comparison to raw samples due to the less energy needed for DSC analysis in fully gelatinized starch (An \& King, 2007; Wang \& Sastry, 1997). The study by An and King (2007) demonstrated the greatest decrease in enthalpy in rice sample with greatest extent of pregelatinization.

Table 1a. Grain dimension of TOX 3145 rice samples

\begin{tabular}{llll}
\hline Properties & Traditional parboiled & IRAD parboiled & Non-parboiled \\
\hline Grain dimension & & & \\
Length (mm) & $7.23 \pm 0.23^{\mathrm{a}}$ & $6.85 \pm 0.25^{\mathrm{b}}$ & $6.73 \pm 0.47^{\mathrm{b}}$ \\
Width $(\mathrm{mm})$ & $1.89 \pm 0.07^{\mathrm{a}}$ & $1.87 \pm 0.10^{\mathrm{a}}$ & $1.84 \pm 0.09^{\mathrm{a}}$ \\
Length/width (mm) & $3.82 \pm 0.17^{\mathrm{a}}$ & $3.67 \pm 0.24^{\mathrm{a}}$ & $3.66 \pm 0.35^{\mathrm{a}}$ \\
Size & Long & Long & Long \\
Shape & Slender & Slender & Slender \\
\hline
\end{tabular}

Mean \pm SD values with the same superscript letters in a row are not significantly different $(P>0.05)$. 
Table $1 \mathrm{~b}$. Amylose and gelatinization properties of TOX 3145 rice samples

\begin{tabular}{llll}
\hline Properties & Traditional parboiled & IRAD parboiled & Non-parboiled \\
\hline Gelatinization & & & \\
$\mathrm{T}_{\mathrm{o}}\left({ }^{\circ} \mathrm{C}\right)$ & - & - & $63.42 \pm 0.04$ \\
$\mathrm{~T}_{\mathrm{p}}\left({ }^{\circ} \mathrm{C}\right)$ & - & - & $67.66 \pm 0.16$ \\
$\mathrm{~T}_{\mathrm{c}}\left({ }^{\circ} \mathrm{C}\right)$ & - & - & $74.02 \pm 1.14$ \\
Amylose $(\%)$ & $20.61 \pm 2.03^{\mathrm{ab}}$ & $17.13 \pm 1.68^{\mathrm{b}}$ & $23.61 \pm 2.32^{\mathrm{a}}$ \\
\hline
\end{tabular}

Mean \pm SD values with the same superscript letters in a row are not significantly different $(P>0.05)$.

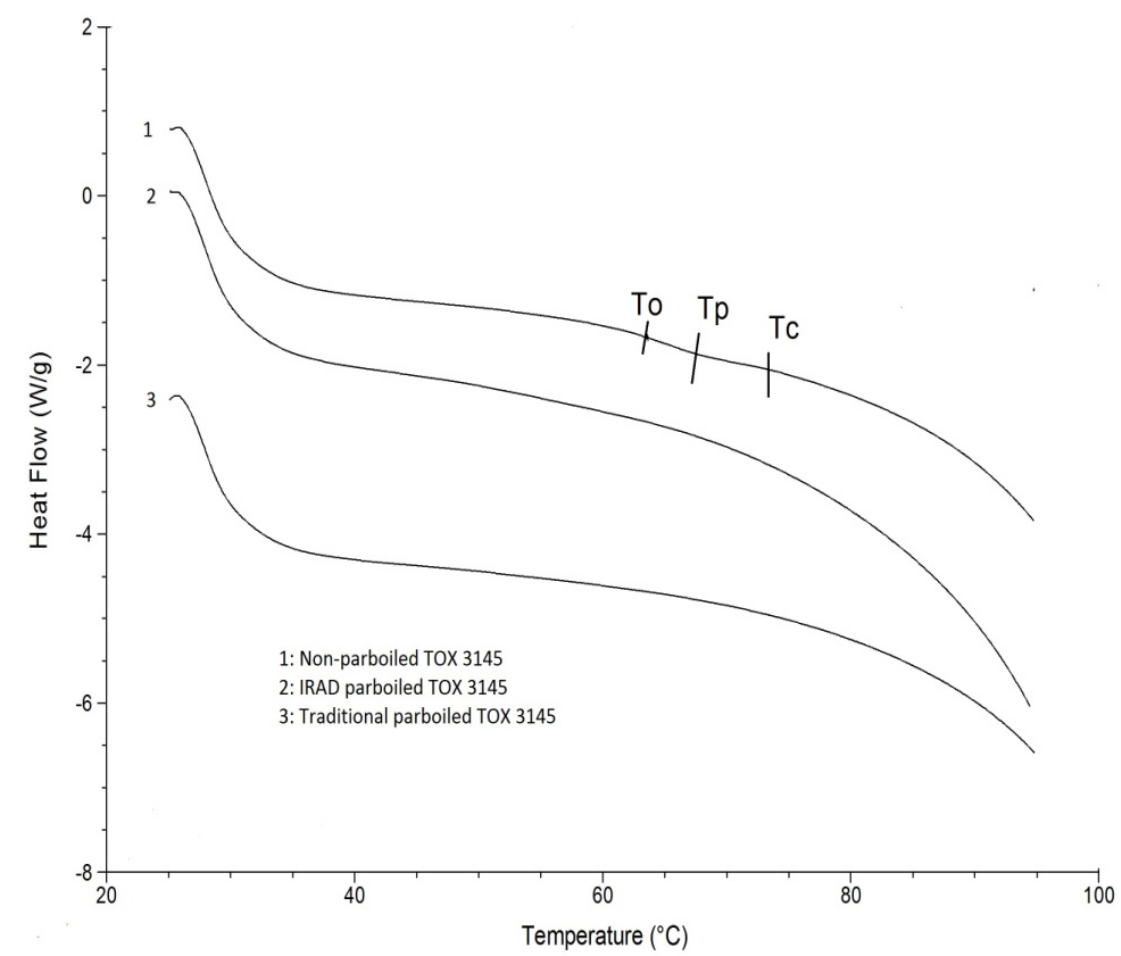

Figure 1. Gelatinization endotherm curves of TOX 3145 rice samples as determined by DSC

$\mathrm{To}=$ Onset temperature; $\mathrm{T} p=$ Peak temperature; $\mathrm{T} c=$ Completion temperature.

Color analysis showed variation in lightness $\left(\mathrm{L}^{*}\right)$, redness $\left(\mathrm{a}^{*}\right)$ and yellowness $\left(\mathrm{b}^{*}\right)$ parameters among samples. The two parboiled samples had an increase degree of lightness $\left(\mathrm{L}^{*}\right)$ after cooking from 51.97-61.75 (TP) and 54.67-61.19 (IRAD). The degree of redness among cooked and uncooked grains varied from -0.80 to -1.01 and 0.3 to 1.52 , respectively while yellowness parameter ranged between 0.42 to 4.01 and 7.59 to 8.44 , respectively. The color parameters in our study is comparable with values reported in previous study (Singh et al., 2011). Singh et al. (2011) reported values between 66.2 to $73.1 ; 0.8$ to 2.4 and 13.6 to 17.5 for lightness, redness and yellowness parameters, respectively among three milled rice varieties. The pattern of increased lightness parameter with consequent reduction in both redness and yellowness parameters observed in TP and IRAD samples revealed that parboiling process brighten the color of cooked grain. Adu-Kwarteng et al. (2003) observed similar pattern of higher lightness parameter with decreased redness and yellowness parameter among rice varieties in Ghana. The preference for white and translucent cooked grains by rice consumer had been documented (Fofana et al., 2011; Adu-Kwarteng et al., 2003). 
Table 2. Color properties of TOX 3145 rice samples

\begin{tabular}{llll}
\hline Properties & Traditional parboiled & IRAD parboiled & Non-parboiled \\
\hline Color (Uncooked grain) & & & \\
L & $51.97 \pm 0.50^{\mathrm{c}}$ & $54.67 \pm 0.21^{\mathrm{b}}$ & $64.20 \pm 0.40^{\mathrm{a}}$ \\
$\mathrm{a}$ & $1.52 \pm 0.11^{\mathrm{a}}$ & $0.30 \pm 0.06^{\mathrm{c}}$ & $0.96 \pm 0.09^{\mathrm{b}}$ \\
$\mathrm{b}$ & $8.44 \pm 0.23^{\mathrm{a}}$ & $7.59 \pm 0.10^{\mathrm{c}}$ & $8.13 \pm 0.14^{\mathrm{b}}$ \\
Color (Cooked grain) & & \\
L & $61.75 \pm 0.47^{\mathrm{a}}$ & $61.19 \pm 1.50^{\mathrm{a}}$ & $59.42 \pm 1.43^{\mathrm{a}}$ \\
$\mathrm{a}$ & $-0.80 \pm 0.08^{\mathrm{c}}$ & $-1.19 \pm 0.10^{\mathrm{a}}$ & $-1.01 \pm 0.07^{\mathrm{b}}$ \\
$\mathrm{b}$ & $4.01 \pm 0.08^{\mathrm{a}}$ & $1.0 \pm 0.09^{\mathrm{b}}$ & $0.42 \pm 0.34^{\mathrm{c}}$
\end{tabular}

Mean \pm SD values with the same superscript letters in a row are not significantly different $(\mathrm{P}>0.05)$.

Cooking characteristics of the samples of TOX 3145 rice are presented in Table 3. The lowest cooking time was observed in NP (17.9 min) while parboiled samples had 19.4-19.7 min. Lower cooking time leads to less fuel and energy consumption during cooking. The MCT in our study is consisting with the duration of 13 to 24 min reported on 23 milled rice varieties in India (Singh et al., 2005). Bocevska et al. (2009) reported MCT of 17.5 to $22.5 \mathrm{~min}$ for milled rice varieties.

The ratio of water uptake (2.69) and elongation (1.38) was higher in NP grains than the parboiled counterparts. The water uptake ratio and elongation ratio between TP and IRAD were statistically similar $(\mathrm{P}>0.05)$.

Table 3. Cooking characteristics of TOX 3145 rice samples

\begin{tabular}{llll}
\hline Properties & Traditional parboiled & IRAD parboiled & Non-parboiled \\
\hline MCT (min) & $19.37 \pm 0.68^{\mathrm{a}}$ & $19.73 \pm 0.36^{\mathrm{a}}$ & $17.90 \pm 0.70^{\mathrm{b}}$ \\
Water uptake ratio & $2.44 \pm 0.06^{\mathrm{b}}$ & $2.63 \pm 0.01^{\mathrm{ab}}$ & $2.69 \pm 0.10^{\mathrm{a}}$ \\
Elongation ratio & $1.22 \pm 0.08^{\mathrm{b}}$ & $1.26 \pm 0.13^{\mathrm{b}}$ & $1.38 \pm 0.12^{\mathrm{a}}$ \\
\hline
\end{tabular}

Mean \pm SD values with the same superscript letters in a row are not significantly different $(P>0.05)$.

$\mathrm{MCT}=$ Minimum cooking time.

The textural properties of samples at MCT are presented in Figure 2. Hardness and elastic modulus parameters showed values between 18.1-36.8 $\mathrm{N}$ and $18.8-41.3 \mathrm{~N} / \mathrm{mm}$, respectively. TP sample depicted significantly highest stiffness and maximum force $(41.3 \mathrm{~N} / \mathrm{mm}$ and $36.8 \mathrm{~N}$, respectively) while lowest values were found in NP sample $(18.8 \mathrm{~N} / \mathrm{mm}$ and $18.1 \mathrm{~N}$, respectively). A similar result of more hardness in cooked grains of parboiled rice than non-parboiled counterpart was reported by Bello et al. (2006). Hardness is an important textural characteristic that influences palatability of cooked rice (Bello et al., 2006; Zhout et al., 2002).

The adhesiveness and gumminess values among samples ranged between -0.8 to $-1.5 \mathrm{~J}$ and 3.2 to $6.4 \mathrm{~J}$, respectively. NP sample also had lowest gumminess $(3.2 \mathrm{~J})$ with the highest value for adhesiveness $(-0.8 \mathrm{~J})$. Gumminess is the energy required to disintegrate a semi-solid food to a readiness for swallowing. 


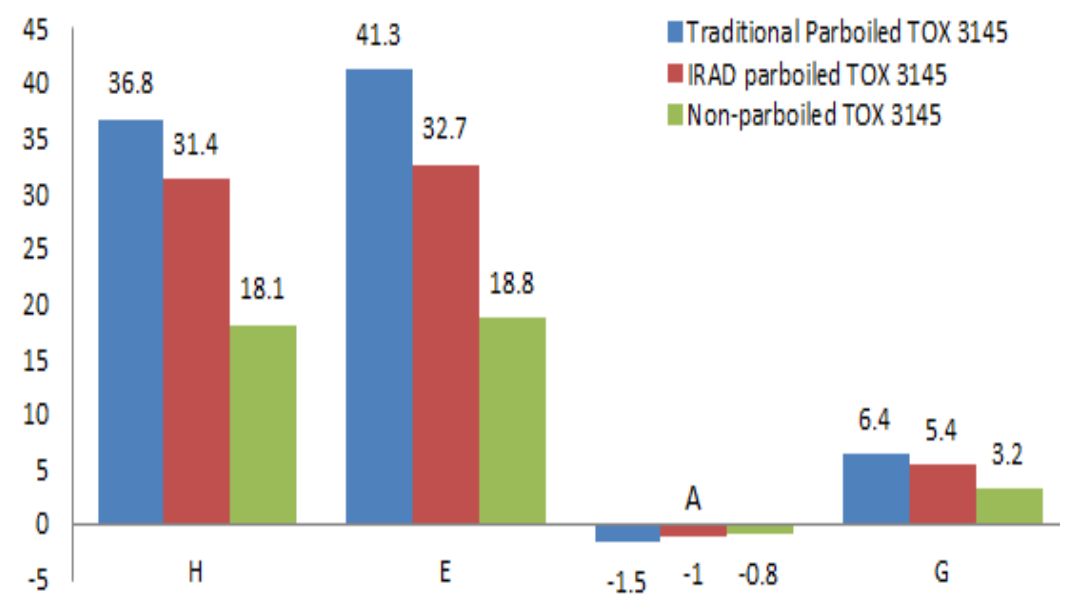

Figure 2. Texture Profile Analysis of TOX 3145 rice varieties

$\mathrm{H}=$ Hardness $(\mathrm{N}) ; \mathrm{E}=$ Elastic modulus $(\mathrm{N} / \mathrm{mm}) ; \mathrm{A}=$ Adhesiveness $(\mathrm{J}) ; \mathrm{G}=$ Gumminess $(\mathrm{J})$.

The relationship of cooking characteristic with grain appearance, amylose content and textural properties are presented in Table 4 . The length of the uncooked grain positively correlated with length/width ratio $(\mathrm{r}=0.71 ; \mathrm{P}<$ $0.05)$, amylose $(\mathrm{r}=0.93 ; \mathrm{P}<0.0)$ and negatively with elongation ratio of cooked grain $(\mathrm{r}=-0.81 ; \mathrm{P}<0.05)$. A similar result of negative correlation between length and elongation $(r=-0.72 ; \mathrm{P}<0.05)$ was reported by Bocevska et al. (2009) in milled rice grain of japonica varieties.

Table 4. Correlation coefficient (r) among physicochemical characteristics of milled TOX 3145 rice samples

\begin{tabular}{llllllllllll}
\hline Parameters & $\mathrm{L}$ & $\mathrm{W}$ & $\mathrm{L} / \mathrm{W}$ & $\mathrm{L}^{*}$ & $\mathrm{a}^{*}$ & $\mathrm{~b}^{*}$ & $\mathrm{ER}$ & $\mathrm{WU}$ & $\mathrm{H}$ & $\mathrm{EM}$ & AM \\
\hline Grain length (L) & 1 & & & & & & & & & & \\
Grain Width (W) & 0.12 & 1 & & & & & & & & & \\
L/W ratio & $0.71^{*}$ & -0.61 & 1 & & & & & & & & \\
Brightness of cooked & -0.55 & -0.33 & -0.10 & 1 & & & & & & & \\
grain (L*) & & & & & & & & & & & \\
Redness of cooked grain & 0.31 & 0.25 & -0.03 & -0.32 & 1 & & & & & & \\
(a*) & & & & & & & & & & & \\
Yellowness of cooked & -0.26 & -0.07 & -0.11 & 0.45 & $-0.69^{*}$ & 1 & & & & & \\
grain (b*) & & & & & & & & & & & \\
Elongation ratio (ER) & $-0.81^{*}$ & -0.13 & -0.55 & 0.25 & -0.11 & 0.15 & 1 & & & & \\
Water uptake (WU) & -0.79 & 0.03 & -0.53 & $0.92^{*}$ & -0.69 & 0.71 & 0.59 & 1 & & & \\
Hardness (H) & -0.33 & 0.16 & -0.32 & 0.78 & -0.72 & 0.68 & 0.13 & 0.77 & 1 & & \\
Elastic modulus (EM) & -0.32 & 0.45 & -0.55 & 0.76 & -0.49 & 0.64 & 0.29 & 0.78 & $0.91^{*}$ & 1 & \\
Amylose (AM) & $0.93^{* *}$ & 0.01 & -0.60 & 0.59 & -0.50 & 0.59 & 0.78 & $0.84 *$ & 0.54 & 0.50 & 1 \\
\hline
\end{tabular}

Levels of significance: **P $<0.01, * \mathrm{P}<0.05$; NS: Not significant $(\mathrm{P}>0.05)$.

Water uptake was significantly associated with amylose content $(\mathrm{r}=0.84 ; \mathrm{P}<0.05)$. Also, a positive but weak correlation was found between water uptake and elongation $(\mathrm{r}=0.59 ; \mathrm{P}>0.05)$. This finding is consistent with a previous report on local rice variety in Nigeria (Danbaba et al., 2011). The study by Danbaba et al. (2011) found that water uptake had a significant and positive correlation with elongation and amylose content.

Water uptake was significantly associated to lightness parameter of cooked grain $(r=0.92 ; \mathrm{P}<0.05)$. As 
expected, the redness $\left(\mathrm{a}^{*}\right)$ and yellowness $\left(\mathrm{b}^{*}\right)$ parameters were inversely related $(\mathrm{r}=-0.69 ; \mathrm{P}<0.05)$. This observation is in line with the negative correlation of water uptake with redness parameter and positively related to yellowness parameter.

Hardness of the cooked grain showed a significant relationship with the elastic modulus $(r=0.91 ; \mathrm{P}<0.05)$. The textural properties of these samples were positively associated to water uptake during cooking, brightness of cooked grain and amylose content, although the correlation was not significant $(\mathrm{P}>0.05)$.

The characteristic of rice grain during cooking is relevant to both consumers and product manufacturers. During cooking, the extent of water uptake by rice grain influences the product volume which is considered an economic issue.

\section{Conclusion}

This study provides information on the physicochemical properties and cooking characteristics of TOX 3145 rice in the raw and parboiled forms as consumed in Cameroon. The grain dimension of the three samples of TOX 3145 rice were statistically similar in size (long) and shape (slender). Amylose composition was reduced in the two parboiled samples which consequently led to absence of gelatinization. The heating intensity as described in these two parboiling procedures could be linked to the absence of gelatinization. MCT of all samples is consistent with the duration of 13 to 24 min reported in literature. Textural properties varied among samples, significant highest stiffness and hardness was found in TP sample. The pattern of increased lightness parameter observed in TP and IRAD samples confirmed that parboiling process brighten the color of cooked grain. Relationship among parameters in this study revealed that amylose content had positive correlation with cooking characteristics. The extent of water absorption during cooking had positive influence on grain elongation, lightness and textural properties.

\section{Acknowledgements}

This study was supported by the Canadian International development Agency(CIDA) project on enhancing food security in Africa through the improvement of rice post-harvest handling, marketing and the development of new rice-based products.

\section{References}

Adu-Kwarteng, E., Ellis, W., Oduro, I., \& Manful, J. (2003). Rice grain quality: a comparison of local varieties with new varieties under study in Ghana. Food Control, 14(7), 507-514. http://dx.doi.org/10.1016/S0956-7135(03)00063-X

An, H., \& King, J. (2007). Thermal characteristics of ohmically heated rice starch and rice flours. Journal of Food Science, 72(1), C084-C088. http://dx.doi.org/10.1111/j.1750-3841.2006.00239.x

Bello, M., Baeza, R., \& Tolaba, M. (2006). Quality characteristics of milled and cooked rice affected by hydrothermal treatment. Journal of Food Engineering, 72(2), 124-133. http://dx.doi.org/10.1016/j.jfoodeng.2004.11.026

Bocevska, M., Aldabas, I., Andreevska, D., \& Ilieva, V. (2009). Gelatinization behavior of grains and flour in relation to physico - chemical properties of milled rice (Oryza sativaL.). Journal of Food Quality, 32(1), 108-124. http://dx.doi.org/10.1111/j.1745-4557.2008.00239.x

Danbaba, N., Anounye, J. C., Gana, A. S., Abo, M. E., \& Ukwungwu, M. N. (2011). Grain quality characteristics of Ofada rice (Oryza sativa L.): Cooking and eating quality. International Food Research Journal, 18, 619-624.

Fan, C., Xing, Y., Mao, H., Lu, T., Han, B., Xu, C., ... Zhang, Q. (2006). GS3, a major QTL for grain length and weight and minor QTL for grain width and thickness in rice, encodes a putative transmembrane protein. Theoretical and Applied Genetics, 112(6), 1164-1171. http://dx.doi.org/10.1007/s00122-006-0218-1

Fofana, M., Futakuchi, K., Manful, J., Bokossa, Yaou, I., Dossou, J., \& Bleoussi, R. (2011). Rice grain quality: A comparison of imported varieties, local varieties with new varieties adopted in Benin. Food control, 22(12), 1821-1825. http://dx.doi.org/10.1016/j.foodcont.2011.04.016

Goufo, P. (2008). Evaluating the constraints and opportunities for sustainable rice production in Cameroon. Research Journal of Agriculture and Biological Sciences, 4(6), 734-744.

Gridley, H., Jones, M., \& Wopereis-Pura, M. (2002). Development of new rice for Africa (NERICA) and participatory varietal selection. Breeding rainfed rice for drought-prone environments: integrating 
conventional and participatory plant breeding in South and Southeast Asia: proceedings of a DFID Plant Sciences Research Programme/IRRI Conference (pp. 12-15).

Hermansson, M., \& Svegmark, K. (1996). Developments in the understanding of starch functionality. Trends Food Science and Technololgy, 7, 345-353.http://dx.doi.org/10.1016/S0924-2244(96)10036-4

Juliano, B. O., Perez, C. M., Blakeney, A. B., Breckenridge, C., Castilo, D. T., Kongseree, N., ... Webb, D. (1981). International cooperative testing on amylose content of milled rice. Starke, 33, 157-162. http://dx.doi.org/10.1002/star.19810330504

Lim, S. T., Lee, J. H., Shin, D. H., \& Lim, H. S. (1999). Comparison of protein extraction solutions for rice starch isolation and effects of residual protein content on starch pasting properties. StarchStärke, 51, 410-415. http://dx.doi.org/10.1002/(SICI)1521-379X(199904)51:4<120::AID-STAR120>3.3.CO;2-1

Mohapatra, D., \& Bal, S. (2006). Cooking quality and instrumental textural attributes of cooked rice for different

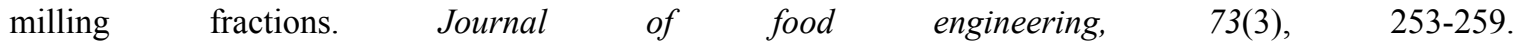
http://dx.doi.org/10.1016/j.jfoodeng.2005.01.028

Nguefack, J., Torp, J., Leth, V., Dongmo, J. L., Fotio, D., \& Zollo, P. A. (2007). Effects of plant extracts and chemical fungicide in controlling a rice seed-borne fungus under laboratory and in irrigated cropping system in Ndop-Cameroon. 8th African Crop Science Society Conference, El-Minia, Egypt, 27-31 October 2007. African Crop Science Society (pp. 791-796).

Singh, N., Kaur, L., Singh Sodhi, N., \& Singh Sekhon, K. (2005). Physicochemical, cooking and textural properties of milled rice from different Indian rice cultivars. Food Chemistry, 89(2), 253-259. http://dx.doi.org/10.1016/j.foodchem.2004.02.032

Singh, N., Pal, N., Mahajan, G., Singh, S., \& Shevkani, K. (2011). Rice grain and starch properties: Effects of $\begin{array}{llll}\text { nitrogen fertilizer application. Carbohydrate Polymers, } & 86(1), \quad 219-225 .\end{array}$ http://dx.doi.org/10.1016/j.carbpol.2011.04.039

Wang, W. C., \& Sastry, S. K. (1997). Starch gelatinization in ohmic heating. Journal of food engineering, 34(3), 225-242. http://dx.doi.org/10.1016/S0260-8774(97)00085-X

Yeh, A. I., \& Li, J. Y. (1996). A continuous measurement of swelling of rice starch during heating. Journal of Cereal Science, 23, 277-283. http://dx.doi.org/10.1006/jcrs.1996.0028

Zhout, Z., Robards, K., Helliwell, S., \& Blanchard, C. (2002). Ageing of stored rice: changes in chemical and physical attributes. Journal of Cereal Science, 35, 65-78. http://dx.doi.org/10.1006/jcrs.2001.0418

\section{Copyrights}

Copyright for this article is retained by the author(s), with first publication rights granted to the journal.

This is an open-access article distributed under the terms and conditions of the Creative Commons Attribution license (http://creativecommons.org/licenses/by/3.0/). 